\title{
Nitrogen fertilizer on yield of fodder maize, chemical composition, its preference and digestibility by Sokoto Gudali heifers \\ ${ }^{1}$ Nwamo, A. C., ${ }^{2}$ Adegbite, J. A., ${ }^{2}$ Olorunnisomo, O. A. \\ ${ }^{\prime}$ National Veterinary Research Institute, Vom, Plateau state, Nigeria \\ ${ }^{2}$ University of Ibadan, Department of Animal Science, Ibadan, Oyo Sate, Nigeria \\ *Corresponding Author: akuchi.nwamo@yahoo.com; +2348035739034
}

\section{Abstract}

The lack of high yielding quality fodder for ruminant production is still a major problem to livestock sector in Nigeria. Fodder yield is primarily determined by nitrogen levels in the soil which is often limiting in tropical soils. This study evaluated four levels of nitrogen fertilizer application $(0,100,150$ and $200 \mathrm{~kg} N / \mathrm{ha}$ ) on fodder yield of maize, chemical composition, its acceptability and digestibility by Sokoto Gudali heifers. Treatments were replicated three times on plots measuring $4 m \times 10$ m in a completely randomized design. Forage was harvested at 42 days after planting (DAP) and fodder yield (tons/ha) per plot was determined. Samples offorage from each plot were taken for chemical analysis. Eight heifers were used to evaluate acceptability and twelve heifers for digestibility of the fodder using standard procedures. The biomass yield increased significantly $(P<0.05)$ with increasing levels of nitrogen fertilizer with the highest yield (9.06 tons $/ \mathrm{ha}$ ) recorded at $200 \mathrm{~kg} N / \mathrm{ha}$. The CP and NDF also increased significantly $(P<0.05)$ with increased levels of nitrogen across the treatment. The highest $C P$ $(23.25 \%)$ and $N D F(75.15 \%)$ were recorded at $200 \mathrm{~kg} \mathrm{~N} / \mathrm{ha}$ and the lowest CP (17.51\%) and $N D F(71.40 \%)$ at $0 \mathrm{~kg} N /$ ha. Preference of heifers for maize fodder reduced with application of fertilizer while digestibility of the maize fodder increased up to $100 \mathrm{~kg} N /$ ha and thereafter reduced.

Keywords: Fodder maize, Nitrogen fertilizer, Biomass yield, Nutrient digestibility, Preference.

\section{Introduction}

Green fodder is an essential component of dairy farming thus forms the bulk of cattle feeds. It has always been an extremely important source of nutrient in livestock rations as it provides a required nutrient for milk production as well as in the health of the dairy animal for both developed and developing countries. The quality of fodder determines to a large extent the productivity of dairy animals and the profitability of the dairy production enterprise. The non-availability of high yielding quality fodder round the year aggravates the problem of sustainable dairy farming (Naik et al., 2013). In Nigeria, fodder scarcity is considered a major limiting factor to the livestock industry.
This has made imperative efforts to increase production of fodder through application of fertilizers. The horizontal expansion in fodder production is not feasible due to increasing human population hence the need to increase yield on per unit area basis and one way of doing so is to enhance nitrogen supply to the plant. Nitrogen is an essential element for fodder production. It is mostly required for fodder growth being an essential constituent of plant tissue involved in cell division and elongation. Maize is a short duration fodder with potential for high yields on small plots; however its productivity is limited by the low nitrogen content of African soils (Naik et al., 2012). This can be corrected through application of nitrogen fertilizer which most frequently is the soil 
nutrient that determines yield of fodder maize (Igbal et al., 2006). The soil nutrient not only affects the forage production; it also improves the quality of forage from the view point of its protein content (Ayub et al., 2002). Maize fodder is a valuable feed for ruminants in terms of yield and nutritive value and its use for animal feeding is becoming very important on small scale mixed farms in the tropics (Methu et al., 2006) which has been achieved with the use of nitrogen fertilizer to improve plant yield. This type of forage contributes up to $24 \%$ of the total cattle feed thus making maize production for grain and fodder equally important. Hence, with appropriate nitrogen fertilizer application, green maize fodder can serve as the sole forage in diets of dairy animals (Naik et al., 2012). This study was thus aimed at assessing the fodder yield of maize fertilized with different levels of nitrogen fertilizer, chemical composition, its preference and digestibility by Sokoto Gudali heifers.

\section{Materials and methods Experimental site}

The study was conducted at the Dairy Unit, Teaching and Research Farm, University of Ibadan, Ibadan, Nigeria located within the tropical rain forest of South Western Nigeria. It lies at longitude $3^{\circ} 45^{\mathrm{E}}$ and latitude $7^{\circ} 27 \mathrm{~N}$ and $300 \mathrm{~m}$ above sea level. The laboratory analyses were carried out at the Department of Animal Science, University of Ibadan.

\section{Experimental material}

A yellow hybrid variety of maize seed, SWAN-1 DMR-LSRY (Downy Mildew and Streak Resistant) was used for the study. The seeds were collected from National Agricultural Seed Council (NASC), Ibadan Oyo State and were planted on a plot at the Dairy Unit of the Teaching and Research Farm. The seeds were planted directly by hand at two seeds per hole in a $4 \mathrm{~m} \times 10 \mathrm{~m}$ plot at a spacing of $25 \mathrm{~cm} \times 19 \mathrm{~cm}$ throughout the study giving rise to a population of 421,072plants/ha. These plots were treated with four levels of nitrogen fertilizer at $0,100,150$ and $200 \mathrm{~kg}$ $\mathrm{N} /$ ha respectively and each replicated three times. A space of $1 \mathrm{~m}$ wide path was maintained between the plots to prevent movement of nutrients across the plots with the rows in a north-south direction. After the emergence of the seedlings, thinning was done to maintain the desired plant density.

\section{Experimental diet}

The basal diet was maize fodder planted with varying levels of Nitrogen (Urea) fertilizer application at $0,100,150$ and $200 \mathrm{~kg} \mathrm{~N} / \mathrm{ha}$ respectively. The maize plants were manually harvested at forty two (42) days after planting (DAP) by cutting at about $15 \mathrm{~cm}$ from the base of the plant and chopped to about $3 \mathrm{~cm}$ length with a mechanical chopper. The maize fodder was offered daily at $10 \%$ body weight of the heifers from each dietary treatment. Fresh water was offered free choice on daily basis.

Experimental animals and management

Twelve Sokoto Gudali heifers of about 18 months of age were used for animal trials. The animals were randomly allotted into four treatments with one animal per replicate and three (3) replicates per treatment in a completely randomized experimental design. The heifers were reared under an intensive system housed individually in an open sided pen. Prior to the commencement of the study, the animals were treated against ecto and endo parasites using Ivermectin ${ }^{\circledR}$ $1 \%$ and against bacterial infection using oxytetracycline $20 \%$, oxy-200 L.A® administered at $1 \mathrm{ml}$ per $10 \mathrm{~kg} /$ body weight (BW) of the animal.

\section{Data collection}

Biomass yield of maize fodder

Maize forage yield from each plot at each 


\section{Nwamo, Adegbite, Olorunnisomo}

harvest of forty two (42) days after planting (DAP) was recorded and cumulative yield for each treatment was determined. The samples were weighed using a spring balance immediately in the field to get the fresh weight. The total forage yield for each treatment was determined as a summation of yields from the harvest and an average of yields from the three replicates calculated in tons per ha.

Chemical composition of maize fodder

A representative sample of each treatment diet was collected daily from each plot during each harvest, oven dried at $65^{\circ} \mathrm{C}$, milled and stored in an air tight container for chemical analysis. Dry matter (DM) of diet was determined by drying in forced draught oven at $105^{\circ} \mathrm{C}$ until constant weight was attained. Maize fodder was analyzed for crude protein $(\mathrm{CP})$, acid detergent fibre (ADF), neutral detergent fibre (NDF) and acid detergent lignin (ADL). Proximate analysis was done using the methods of AOAC, (2005). Detergent fibre content was determined by the methods of Van Soest et al. (1991).

\section{Preference by Sokoto Gudali heifers}

Eight Sokoto Gudali heifers were used for this study to evaluate the free choice intake of different experimental fodders for a period of 7days. The animals were housed together in an open enclosure and maize fodder fed were harvested daily and chopped with a mechanical chopper. The observation lasted for 45 minutes each day for 7 days. The quantity of feed offered and feed refused was determined. There was free access to fresh water on daily basis. Acceptability of the maize fodder was assessed by Co-efficient of Preference (Babayemi, 2007) and Percentage Preference (Olorunnisomo, 2011). Co-efficient of Preference (CoP) was calculated as:

$\mathrm{CoP}=\underline{\text { Intake of individual forage }}$ Average intake of forage
When $\mathrm{CoP}>1=$ Maize fodder was regarded as acceptable.

CoP $<1=$ Maize fodder was

regarded as not acceptable.

Percentage preference was calculated as:

$\%$ Preference $=$

Individual intake of forage $\times 100$

Total intake of forage

Digestibility trial

Twelve Sokoto Gudali heifers were used for the digestibility trial. The animals were randomly assigned to four treatment diets of $\mathrm{N}_{0}, \mathrm{~N}_{100}, \mathrm{~N}_{150}$, and $\mathrm{N}_{200}$ respectively and housed in individual pens. Each treatment had three replicates with one animal per treatment. A known quantity of each treatment diet was fed to the animals for 14days. Leftover feed and faeces were collected, weighed and recorded. In-situ faecal collection method was used for collecting samples of the faeces. This is done by collecting faeces as soon as it was voided. $10 \%$ of the faeces voided was taken daily from each animal (after thorough mixing) for moisture determination, oven dried at $65^{\circ} \mathrm{C}$, milled and kept in an air tight containers for chemical analysis.

Apparent digestibility of the diets was calculated as the difference between the quantity of feed ingested and faeces voided by the animals, expressed as a percentage using the following equation:

$$
\left.\mathrm{D}_{\mathrm{x}}=\frac{\left(F_{O} \times A o\right)-F_{l}}{F_{O} \times \mathrm{XA}_{l}}\right) \times 100
$$

Where $\mathrm{D}_{\mathrm{x}}=$ Digestibility coefficient of nutrient

$F_{o}=$ Quantity of feed consumed in grammes (DM)

$\mathrm{A}_{\mathrm{o}}=$ Percent nutrient content in feed (DM)

$\mathrm{F}_{1}=$ Quantity of faeces voided in grammes (DM)

$\mathrm{A}_{1}=$ Percent nutrient content in faeces (DM)

Statistical analysis

All data obtained from the experiment were subjected to descriptive statistics and 
analysis of variance at $\alpha=0.05$, using Statistical Analysis Software (SAS, 1999) while significant means were separated using Duncan`s Multiple Range Test (DMRT) of the same software package.

\section{Results}

The biomass yield (tons/ha) of maize fodder with varying levels of nitrogen fertilizer application at 42 days of growth is presented in Table 1 . There was significant increase in yield with fertilizer application as the yield from nitrogen treatment of $200 \mathrm{~kg}$ $\mathrm{N} / \mathrm{ha}$ (9.06 tons/ha) was significantly higher than yield from nitrogen treatments of $150 \mathrm{~kg}$ $\mathrm{N} / \mathrm{ha}(7.15 \mathrm{tons} / \mathrm{ha}), 100 \mathrm{~kg} \mathrm{~N} / \mathrm{ha}$ (5.90tons/ha) and 0kg N/ha (4.62 tons/ha), respectively.

Table 1: Mean values for biomass yield (tons/ha) of maize fodder with varying levels of nitrogen fertilizer application at 42days of growth

\begin{tabular}{|c|c|c|c|c|c|}
\hline $\begin{array}{l}\text { Biomass yield } \\
\text { (tons/ha) }\end{array}$ & $\mathrm{N}_{0}$ & $\mathrm{~N}_{100}$ & $\mathrm{~N}_{150}$ & $\mathrm{~N}_{200}$ & SEM \\
\hline & $4.62^{\mathrm{d}}$ & $5.90^{c}$ & $7.15^{b}$ & $9.06^{\mathrm{a}}$ & 258.60 \\
\hline
\end{tabular}
respectively. SEM = Standard Error of Mean.

The chemical composition of the maize fodder fed is presented in Table 2. There was no significant difference $(\mathrm{P}>0.05)$ in the dry matter content of the maize fodder fed. Crude protein was significantly different $(\mathrm{P}<0.05)$ across the dietary treatments with $\mathrm{N}_{200}$ having the highest value of $23.25 \%$ and $\mathrm{N}_{0}$ having the lowest value of $17.51 \%$. The Neutral detergent fibre was significantly different $(\mathrm{P}<0.05)$ across the dietary treatments with $\mathrm{N}_{200}$ having the highest NDF of $75.15 \%$ and $\mathrm{N}_{0}$ having the lowest of $71.40 \%$ while ADF of $\mathrm{N}_{0}$ and $\mathrm{N}_{100}$ were similar but different from 32.80 and 32.20 in $\mathrm{N}_{150}$ and $\mathrm{N}_{200}$ respectively. The ADL in $\mathrm{N}_{100}$ (16.80) was significantly higher $(\mathrm{P}<0.05)$ than statistically similar values of 15.50, 15.30 and 15.10 in $\mathrm{N}_{0,} \mathrm{~N}_{150}$ and $\mathrm{N}_{200}$, respectively.

Table 2: Chemical composition of maize fodder with varying levels of fertilizer application at 42 days of growth

\begin{tabular}{llllll}
\hline Parameters $(\%)$ & $\mathrm{N}_{0}$ & $\mathrm{~N}_{100}$ & $\mathrm{~N}_{150}$ & $\mathrm{~N}_{200}$ & SEM \\
\hline $\mathrm{DM}$ & 25.52 & 24.02 & 24.25 & 23.73 & 0.25 \\
$\mathrm{CP}$ & $17.51^{\mathrm{d}}$ & $20.65^{\mathrm{c}}$ & $22.05^{\mathrm{b}}$ & $23.25^{\mathrm{a}}$ & 0.23 \\
$\mathrm{NDF}$ & $71.40^{\mathrm{c}}$ & $72.20^{\mathrm{c}}$ & $73.90^{\mathrm{b}}$ & $75.15^{\mathrm{a}}$ & 0.23 \\
ADF & $35.70^{\mathrm{a}}$ & $35.30^{\mathrm{a}}$ & $32.80^{\mathrm{b}}$ & $32.20^{\mathrm{b}}$ & 0.25 \\
ADL & $15.50^{\mathrm{b}}$ & $16.80^{\mathrm{a}}$ & $15.30^{\mathrm{b}}$ & $15.10^{\mathrm{b}}$ & 0.25 \\
\hline
\end{tabular}

$\overline{a, b, c}$ Means with different superscripts on the same row differ significantly $(\mathbf{P}<0.05) ; \mathbf{N}_{,}, \mathbf{N}_{100}, \mathbf{N}_{150}, \mathbf{N}_{200}=$ treatments at 0,100,150,200kg N/ha respectively. DM=Dry matte r; $\mathrm{CP}=$ crude protein; NDF=Neutral Detergent Fibre; ADF= Acid Detergent Fibre; ADL= Acid Detergent Lignin; SEM= Standard Error of Mean

Table 3: Preference of maize fodder with varying levels of fertilizer application fed by Sokoto Gudali heifers

\begin{tabular}{lccccc}
\hline Parameters & $\mathrm{N}_{0}$ & $\mathrm{~N}_{100}$ & $\mathrm{~N}_{150}$ & $\mathrm{~N}_{200}$ & SEM \\
\hline AVFI (kg) & 16.96 & 9.20 & 5.16 & 5.88 & - \\
CoP & $1.83^{\mathrm{a}}$ & $0.97^{\mathrm{b}}$ & $0.56^{\mathrm{c}}$ & $0.63^{\mathrm{bc}}$ & 0.06 \\
$\%$ Pref. & $45.89^{\mathrm{a}}$ & $24.26^{\mathrm{b}}$ & $13.97^{\mathrm{c}}$ & $15.93^{\mathrm{bc}}$ & 1.60 \\
\hline
\end{tabular}

$\overline{a, b, c}$ Means with different superscripts on the same row differ significantly $(P<0.05) . N_{0}, N_{100}, N_{150,}, N_{200}=$ treatments at $0,100,150,200 \mathrm{~kg} N / h a$ respectively. AVFI $(\mathrm{kg})=$ Average Feed Intake in kilogram; CoP = Coefficient of Preference; \% Pref. = Percentage Preference; $\mathrm{S}$ EM= Standard Error of Mean. 


\section{Nwamo, Adegbite, Olorunnisomo}

The Preference of maize fodder by Sokoto Gudali heifers between the treatments presented in Table 3 shows the Average Feed Intake (AVFI), Coefficient of Preference (CoP) and Percentage Preference. $\mathrm{N}_{0}$ showed $\mathrm{CoP}$ of 1.83 which was significantly different $(\mathrm{P}<0.05)$ from $\mathrm{N}_{100}, \mathrm{~N}_{150,}$ and $\mathrm{N}_{200}$. Same trend was observed for percentage preference with $\mathrm{N}_{0}$ (45.89) significantly different $(\mathrm{P}<0.05)$ from $\mathrm{N}_{100}$ (24.26), $\mathrm{N}_{150}(13.97)$ and $\mathrm{N}_{200}(15.93)$, respectively.

Table 4: Mean values for the Dry Matter Digestibility (DMD) of maize fodder with varying levels of fertilizer application fed by Sokoto Gudali heifers

\begin{tabular}{lccccc}
\hline Parameters & $\mathrm{N}_{0}$ & $\mathrm{~N}_{100}$ & $\mathrm{~N}_{150}$ & $\mathrm{~N}_{200}$ & SEM \\
\hline FI $(\mathrm{kg}, \mathrm{DM})$ & $243.20^{\mathrm{d}}$ & $305.05^{\mathrm{c}}$ & $347.25^{\mathrm{b}}$ & $353.01^{\mathrm{a}}$ & 0.21 \\
FO $(\mathrm{kg}, \mathrm{DM})$ & $42.78^{\mathrm{d}}$ & $45.96^{\mathrm{c}}$ & $70.86^{\mathrm{b}}$ & $73.06^{\mathrm{a}}$ & 0.27 \\
DMD $(\%)$ & $82.41^{\mathrm{b}}$ & $84.93^{\mathrm{a}}$ & $79.60^{\mathrm{c}}$ & $79.30^{\mathrm{c}}$ & 0.32 \\
\hline ab.,c & Men &
\end{tabular}

$\overline{a, b, c}$ Means with different superscripts on the same row differ significantly $(\mathbf{P}<0.05) . \mathbf{N}_{0}, \mathbf{N}_{100,}, \mathbf{N}_{150,}, \mathbf{N}_{200}=$ treatments at $0,100,150,200 \mathrm{~kg} \mathbf{N} / \mathrm{ha}$ respectively. FI = Feed Intake; FO = Faecal Output; kg, DM= kilogram, dry matter; DMD $(\%)=$ Dry Matter Digestibility in percentage; SEM= Standard Error of Mean.

Table 4 shows the dry matter digestibility (DMD) and feed intake (FI) of maize fodder as well as faecal output (FO) voided by Sokoto Gudali heifers. It revealed that there were significant differences $(\mathrm{P}<0.05)$ across treatment $\mathrm{N}_{0}, \mathrm{~N}_{100}$ and $\mathrm{N}_{150 \text {, }}$ respectively with $\mathrm{N}_{100}$ (84.93) having the highest \%DMD and $\mathrm{N}_{150}(79.60)$ having the least \%DMD. Treatments $\mathrm{N}_{150}(79.60)$ and $\mathrm{N}_{200}$ (79.42) were not significantly different from each other. There were significant differences $(\mathrm{P}<0.05)$ for FI and FO across the treatment.

\section{Discussion}

The nitrogen requirement for fodder maize production was determined from field experimentation involving different levels of nitrogen application. This included experimental plots subjected to different treatment levels of nitrogen fertilizer (Urea) and it was observed to have significantly influenced the yield across the treatments. Several studies (Krishna et al., 1998; Cox and Cherney, 2001; Girija, 2002) have reported that the application of nitrogen fertilizer at different levels increased maize fodder. This variation in yield among nitrogen levels can be attributed to more availability of nitrogen with the increase in application. This result confirmed the findings of Aslam et al. (2011); Shehzad et al. (2012) and Ayub et al. (2013). According to Hasabul et al. (2014) the application of increased level of nitrogen fertilizer presumably increased the availability of soil nitrogen, which might have enhanced the meristematic growth and resulted in higher maize fodder yield. The biomass yield observed in the nitrogen treatments showed a significant increase by increasing nitrogen application with treatment $200 \mathrm{~kg} \mathrm{~N} /$ ha higher (9.06 tons $/ \mathrm{ha}$ ) than other nitrogen treatments. The results are quite in line with those of Johnston (2000) and Mahmud et al. (2003) that nitrogen is a major element necessary for plant growth and development and at $200 \mathrm{~kg}$ N/ha (Almodares et al., 2009) produced the highest biomass of maize fodder while its limit reduced yield (Mengel and Kirkby, 2001). Although the yield was highest at $\mathrm{N}_{200}$ (200kg N/ha) but this did not meet the requirement of maize green fodder yield ranging from $10-50 \mathrm{t} / \mathrm{ha}$ as stated by FAO (2016); this could be as a result of early harvest at 42days and Manga et al., (1991) confirms that biomass and dry matter yield 
of maize increased as the harvest time is delayed, hence time of harvest also determines forage yield. The dry matter (DM) content ranged from $23 \%-26 \%$ which is within the range for maize fodder cited by Heuze et al. (2016) as $12.6 \%$ $47.6 \%$.

The effect of nitrogen treatments on maize fodder (at vegetative stage) and its interaction on percentage crude protein was significant at $0.05 \%$ level. The crude protein content increased significantly $(\mathrm{P}<0.05)$ with increased nitrogen fertilization and this was in accordance with the finding of Mahmud et al. (2003) that the increase in protein contents with increasing fertilizer levels may be as a result of enhancement in amino acid formation due to fertilization. Ayub et al. (2003); Igbal et al. (2006); Ullah et al. (2015) also reported that the increasing nitrogen dose indicated better nitrogen up take by the fodder maize plants, signifying the escalating trend of chlorophyll content resulting to more greenish leaves which was also observed among the treatment groups with $\mathrm{N}_{200}$ having more greener leaves than other treatments. Similar trend was observed by Almodares et al. (2009) at highest nitrogen application of $200 \mathrm{~kg} \mathrm{~N} / \mathrm{ha}$. Fibre factions for maize fodder were shown in Table 2. The Neutral Detergent Fibre values were relatively high ranging from $71.40 \%$ $75.15 \%$ as confirmed by Hoffman et al. (2003) that percentage Neutral Detergent Fibre Digestibility (\%NDFD) of forage is high at vegetative state above $70 \%$ (>70\% of NDF) and low at maturity as increased $\% \mathrm{NDF}$ will result in higher forage intake as observed in their average feed intake. Acid Detergent Fibre ranged from 32.20 $35.70 \%$ and according to Kellems and Church (2001), forages with less than $40 \%$ ADF are categorized as high quality forages while those greater than $40 \%$ are categorized as poor quality forages. Based on this assertion, maize fodder can be classified as high quality forage because their ADF values were below $40 \%$.

The Coefficient of Preference (in ratio) and percentage preference (in \%) of individual forage which measures preference for forages by ruminants shown in Table 3 showed variability in preference. This could be related to the effect of fertilization on forage texture as reported by Olanite et al. (2011) who posited that forage preference is strongly influenced by the physical properties and structure of the plant. As observed in Table 4, as feed intake increased, there was reduction in DMD. This observation was is in line with Khan et al. (2003) on depression in apparent digestibility as level of feed intake increased which may be due to a more rapid movement of feed through the tract, thus allowing less time for digestion and absorption. Studies also showed that livestock usually digest a larger percentage of the nutrients in their feed when fed restrictedly than when fed $a d$ libitum (Okine and Mathison, 1991; Faichney, 1993) while relatively high DMD across the treatment was is in agreement with Azim et al. (2000) and Kim et al. (2001) that DMD of fodder is high at vegetative stage and low at maturity.

\section{Conclusion}

Based on the results obtained from this study, the use of nitrogen fertilizer improved fodder maize production. The fertilized plots $\mathrm{N}_{100}$, $\mathrm{N}_{150}, \mathrm{~N}_{200}$ showed a biomass improvement of $65 \%$ over the unfertilized plot $\mathrm{N}_{0}$ which became more pronounced with increasing fertilizer level and was associated with optimum animal performance and considerable improvement in digestibility.

\section{References}

Almodares, A., Jafarinia, M. and Hadi, M. R. 2009. The Effects of Nitrogen 


\section{Nwamo, Adegbite, Olorunnisomo}

Fertilizeron $\quad \mathrm{C} \mathrm{h}$ e $\mathrm{m} \mathrm{i} \mathrm{c} \mathrm{a} 1$ Compositions in Corn and Sweet Sorghum. American-Eurasian $J$. Agric.\& Environ. Sci., 6(4): 441-446.

AOAC 2005. Official Methods of Analysis, 18th edition. Association of Official Analytical Chemists, Washington DC, USA.

Aslam, M., Iqbal, A., IbniZamir, M. S., Mubeen, M. and Amin, M. 2011. Effect of different nitrogen levels and seed rates on yield and quality of maize fodder. Crop Environ, 2:47-51.

Ayub, M., Nadeem, M. A., Sharar, M. S. and Mahmood, N. 2002. Response of Maize (Zea mays L.) Fodder to Different Levels of Nitrogen and Phosphorus. Asian Journal of Plant Sciences, 1, 352$\begin{array}{llll}3 & 5 & 4\end{array}$. http://dx.doi.org/10.3923/ajps.200 2.352.354.

Ayub, M., Ahmad, R., Nadeem, M. A., Ahmad, B. and Khan, R. M. A. 2003. Effect of different levels of nitrogen and seed rates on growth, yield and quality of maize fodder. Pak. J.Agri. Sci.40: 140-143.

Ayub, M., Tahir, M., Abrar, M. and Khaliq, A. 2013. Yield and quality response of forage maize to nitrogen levels and inoculation with PGPR S CROP \& ENVIRONMENT, 4(1): 35-38.

Azim, A., Khan, A. G., Nadeem, M. A. and Muhammad, D. 2000. Influence of maize and cowpea intercropping on fodder production and characteristics of silage. Asian-Aust. J.Anim. Sci., 13 (6): 781-784.

Babayemi, O. J. 2007. In vitro fermentation characteristics and acceptability by West African dwarf goats of some dry season forages. African Journal of Biotechnology. 6 (10): 1260 1265.

Cox, W. J. and Cherney, J. R. 2001. Row spacing, plant density and nitrogen effects on corn silage. Agronomy Journal, 93: 597-602.

Faichney, G. J. 1993. Digesta flow. In: J.M. Forbes and J. Frence (Eds.) Quantitative Aspects of Ruminant Digestin and Metabolism. P. 53, C.A.B. Int., Wallingford, UK.

FAO, (2016). FAOSTAT. Food and Agriculture Organization of the United Nations, Rome, Italy.

Girija L.D. 2002. Effect of various levels of nitrogen and phosphorus on growth and yield of forage $\quad \mathrm{m} \mathrm{a} \mathrm{i} \mathrm{z}$ e (Zea mays L.). Forage Research, 27(4): 263-266.

Hasabul, I., Kawsar, A. and Fahad, J. 2014. Biomass Yield and Chemical Composition of Maize (Zea mays) Fodder Using Compost as Fertilizer. Ijcbs Research, ISSN: 2349-2724.

Heuzé, V. and Tran, G. 2016. Maize grain. Feedipedia, a programme by INRA, CIRAD, AFZ and FAO. http://www.feedipedia.org/node/55 6.

Hoffman, P. C., Lundberg, K. M., Bauman, L. M. and Shaver, R. D. 2003. The Effect of Maturity on NDF Digestibility. Marshfield Agricultural Research Station. University of Wisconsin - Madison. Focus on Forage, Vol. 5: No. 15.

Igbal, A., Ayoub, M., Zaman, H. and Ahmed, R. 2006. Impact of nutrient management and legumes association on agro qualitative traits of maize forage. Pak. J. Bot. $38,1079-1084$. 
Nitrogen fertilizer on yield of fodder maize, chemical composition, its preference and digestibility by Sokoto Gudali heifers

Johnston, A. E. (2000). Efficient use of nutrients in agricultural production systems. Common Soil Science Plant Annual, 31: 1599-1620.

Kellems, R. O. and Church, D. C. 2001. Livestock feeds and feeding $\left(5^{\text {th }}\right.$ edition). Prentice-Hall Inc., New Jersey, USA, 537p.

Khan, M. N., Nisa, M. and Sarwar, M. 2003. Technique for Measuring Digestibility for the Nutritional Evaluation of Feeds. International Journal of Agric Biology, 5(1): 93 124.

Kim, J. D., Kwon, C. H. and Kim, D. A. 2001. Yield and quality of silage corn as affected by hybrid, maturity, planting date and harvest stage. Asian Aust. J. Anim. Sci, 14: 1705-1711.

Krishna, S. V., Raikhelkar, S. V. and Sambasiva, R. 1998. Effect of planting pattern and nitrogen on fodder maize intercropped with cowpea. Indian Journal ofAgronomy, 43(2): 237-240.

Mahmud, K., Ahmad, I. and Ayub, M. 2003. Effect of Nitrogen and Phosphorus on the Fodder Yield and Quality of Two Sorghum Cultivars (Sorghum bicolor L.). International Journal Agriculture Biology, 5: 61-63.

Manga, N., Tansi, V. and Saglamtimur. 1991. Researches on the effect of harvest time on the forage yield and some agricultural characters of maize cultivars grown as double crop under Cukurova conditions. Turkish 3. Range and Forage Crops Congress Izmir, 399408.

Mengel, K. and Kirkby, E. A. 2001. Principles of Plant Nutrition. Kluwer academic publisher.
Methu, J. N., Kiruiro, E. M. and Abate, A. N. 2006. Your feed shortage problem: Use maize forage. KARI resource center, Nairobi.

Naik, P. K., Swain, B. K., Chakurkar, E. B. and Singh, N. P. 2012. Performance of dairy cows on green fodder maize based ration in coastal hot and humid climate. Animal Nutrition and Feed Technology 12: (2): 265-270.

Naik, P. K., Dhuri, R. B., Swain, B. K., Karunakaran, M., Chakurkar, E. B. and Singh, N. P. 2013. Analysis of existing dairy farming in Goa. Indian Journal of Sciences 83 (3): 299-303.

Okine, E. K. and Mathison, G. W. 1991. External and internal markers for appraising site and extent of digestion in ruminants. J. Dairy Sci., 76: 129.

Olanite, J. A., Arigbede, O. M and Ojo, V. O. A. 2011. Forage Quality and Conservation. Department of Pasture and Range Management, College of Animal Science and Livestock Production, the Federal University of Agriculture,

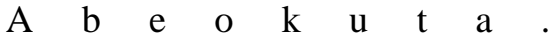
www.unaab.edu.ng/attachments/46 2 PRM 502\%20NOTE.pdf.

Olorunnisomo, O. A. 2011. Silage characteristics and acceptability of elephant grass and cassava peel silage by ruminants in southwest Nigeria. In: Proceedings, 3rd International Conference on Sustainable Animal Agriculture for Developing Countries (SAADC 2011), Volume III, 26 - 29 July, 2011, NakhonRatchasima, Thailand, pp 201-206.

SAS, 1999. Statistical Analysis System SAS, User Guide, SAS/STAT Version 


\section{Nwamo, Adegbite, Olorunnisomo}

$6{ }^{\text {th }}$ Edition, SAS Institute, Inc. Raleigh New Cary, NC, U.S.A. pp 346-350.

Shehzad, M.A., Maqsood, M., Bhatti, M. A., Ahmad, W. and Shahid, M. R. 2012. Effects of nitrogen fertilization rate and harvest time on maize (Zea mays L.) fodder yield and its quality attributes. Asian J. Pharm. Biol. Res, 2 (1):19- 26 .

Ullah, M. I., Khakwani, A. A., Sadiq, M., Awan, I., Munir, M. and Ghazanfarullah. 2015. Effects of nitrogen fertilization rates on growth, quality and economic return of fodder maize (Zea mays L.). Sarhad Journal of Agriculture, 31(1): 45-52.
Van Soest, P. J., Robertson, J. B. and Lewis, B. A. 1991. Methods of dietary fibre, neutral detergent fibre, and non- starch polysaccharides in relation to animal nutrition. Journal of Dairy Science. 74: 3583-3597. 